\title{
PRODUCTIVITY AND PERSISTENCE OF YELLOW SERRADELA (Ornithopus compressus L.) AND BISERRULA (Biserrula pelecinus L.) IN THE MEDITERRANEAN CLIMATE REGION OF CENTRAL CHILE
}

\author{
Alejandro del Pozo ${ }^{1 *}$, and Carlos Ovalle²
}

\begin{abstract}
The production and sustainability of non-irrigated pastures in the Mediterranean climate region of central Chile is currently limited by the low diversity of valuable species and cultivars of annual forage legumes, able to persist in zones with highly variable annual rainfall, and low fertility or poorly drained soils. In this work, DM production, seed yield, hardseededness and pasture persistence were evaluated for cultivars of yellow serradella (Ornithopus compressus L.) and biserrula (Biserrula pelecinus L.), in field experiments conducted in the subhumid portion of the Mediterranean climate region of Chile. Burr medic (Medicago polymorpha L.) and sub clover (Trifolium subterraneum L.) were used as a reference plants. A remarkable DM production and seed yield were observed in biserrula (cvs. Mor96 and Casbah), and in some cultivars of yellow serradella (e.g. Madeira, Santorini); biserrula produced by far the largest number of seeds per $\mathrm{m}^{2}$. As was expected for species that produce very high levels of hard-seeds, the regeneration of biserrula and serradella was low in second growing season, but plant density and productivity were high in the third growing season. The use of biserrula and serradela in monoculture or in mixture with other annual legumes, either in pasture-crop rotation or permanent pasture, would contribute to the improvement of the prevailing productive systems in the Mediterranean climate region of central Chile.
\end{abstract}

Key words: annual legumes, hard-seed, espinal, plant density, seed yield.

\section{INTRODUCTION}

Pastures in the Mediterranean climate region of central Chile are dominated by annual composite and grass species and their productivity is generally low (Ovalle et al., 2006a). The abundance of annual legumes is also very low, being Trifolium glomeratum L. and two species of Medicago (Medicago polymorpha L. and Medicago arabica (L.) Huds.) the most common species (Ovalle et al., 1996). The land use system is based on two basic models, pasture rotated with annual crops (mainly wheat, Triticum aestivum L.) and continuous grazing. The croppasture rotation is mainly used on well-drained hillsides whereas the continuous grazing by sheep and cattle is practiced mainly on flatlands, which are not suitable for cropping because of the frequent and prolonged water logging in winter.

To improve pasture and cereal production in the

${ }^{1}$ Universidad de Talca, Facultad de Ciencias Agrarias, Casilla 747, Talca, Chile. *Corresponding author (adelpozo@utalca.cl).

${ }^{2}$ Instituto de Investigaciones Agropecuarias INIA, Centro Regional de Investigación Quilamapu, Casilla 426, Chillán, Chile.

Received: 29 July 2008.

Accepted: 17 October 2008.
Mediterranean region, an intensive research program has been developed in bur medic (Medicago polymorpha L.) in order to collect and characterize accessions (del Pozo et al., 2002a; 2002b; Paredes et al., 2002), and to select Chilean cultivars (Ovalle et al., 2001; del Pozo et al., 2001) and rhizobium. However, the persistence of bur medic on degraded soils is inconsistent. Therefore, there is a need of insuring pasture persistence as well increasing the diversity of annual legumes, particularly with species producing small and hard-seeds, and have vegetative and reproductive phenology that will ensure persistence in zones with highly variable and unpredictable annual rainfall.

Cultivars of various annual legume species have been developed in Australia during recent years (Dear et al., 2002; Loi et al., 2005); since 1991, 49 new pasture legume cultivars have been developed by public institutions (Nichols et al., 2006). Among these are a number of cultivars of yellow serradella and biserrula. Both species are apparently well adapted to soils of light texture and low phosphorus availability (Paynter, 1990), produce forage of high quality (Freebairn, 1994; Howieson et al., 1995), and have smaller seeds than burr medic (Loi et al., 1999; Ovalle et al., 2003). 
In environments with highly variable and unpredictable annual rainfall, and prolonged dry periods, like the Mediterranean climate region of Chile, vegetative and reproductive phenology, seed production and hardseededness are important traits to ensure pasture persistence. This paper reports results of two field experiments where cultivars of yellow serradella (Ornithopus compressus L.) and biserrula (Biserrula pelecinus L.) were compared with bur medic and sub clover, in the interior dryland of the Mediterranean climate region of Chile. The objective was to evaluate dry matter (DM) production, seed yield, hardseededness and pasture persistence of these annual legumes, and to discuss their possible role in Chilean farming systems.

\section{MATERIALS AND METHODS}

The study site was located at the El Boldo farm of the Experimental Center Cauquenes ( $35^{\circ} 58^{\prime} \mathrm{S}, 72^{\circ} 17^{\prime} \mathrm{W}$; 140 m.a.s.l.), Instituto de Investigaciones Agropecuarias (INIA) in the interior dryland of the Mediterranean climate region of Chile. Long term average of the minimum temperatures of the coldest month (July) is $4.8{ }^{\circ} \mathrm{C}$ and of the maximum temperatures of the warmest month (January) is $29^{\circ} \mathrm{C}$. Mean annual precipitation is $657 \mathrm{~mm}$, concentrated in the seven coldest months of the year. The soil is granitic (fine, kaolinitic, mesic Typic Palexeralfs), sandy clay loam in texture, with low organic matter content (2.6\%), and slightly acid ( $\mathrm{pH} 5.9$ in water), with low $\mathrm{P}\left(5 \mathrm{mg} \mathrm{kg}^{-1}\right)$, and $\mathrm{N}\left(19.8 \mathrm{mg} \mathrm{kg}^{-1}\right)$ levels and medium $\mathrm{K}$ level (128 $\left.\mathrm{mg} \mathrm{kg}^{-1}\right)$.

In the first experiment (Experiment 1), 11 cultivars of four species of annual legumes (Table 1) were tested. A preliminary report was presented in Ovalle et al. (2000). Seed rate was $20 \mathrm{~kg} \mathrm{ha}^{-1}$ for bur medic and sub clover and $8 \mathrm{~kg} \mathrm{ha}^{-1}$ for serradella and biserrula of viable seeds (percentage of germination $>85 \%$ ), and were broadcast sowed on 27 May 1997. Seeds were inoculated with the specific rhizobium (obtained from Centre for Legumes in Mediterranean Agriculture-CLIMA, Australia) for each species at the rate of $10 \mathrm{~g}$ of inoculant per kilogram of seeds, using as adherent methyl cellulose (1\%), and then covered with lime. The experimental design was a randomized complete block with four replicates. Plot size was $2 \times 6 \mathrm{~m}$ in size. Fertilization was applied annually and consisted of $90 \mathrm{~kg} \mathrm{P}_{2} \mathrm{O}_{5} \mathrm{ha}^{-1}, 50 \mathrm{~kg} \mathrm{~K}_{2} \mathrm{O} \mathrm{ha}^{-1}$ and $20 \mathrm{~kg}$ boron calcite ha' ${ }^{-1}$. More prominent weeds were removed by hand but no herbicide was applied.

In the second experiment (Experiment 2) 12 cultivars of four species of annual legumes were evaluated (Table 1). Sowing date was 6 June 2000. Seeding rate was equivalent to $16 \mathrm{~kg} \mathrm{ha}^{-1}$ for bur medic and sub clover, and $9 \mathrm{~kg} \mathrm{ha}^{-1}$ for serradella and biserrula seeds. Seeds were sowed using a manual drill machine (Planet Junior, USA). The experimental design was a randomized complete block with four replicates. Plot size was 2 x 5 m. Fertilization consisted of $92 \mathrm{~kg} \mathrm{P}_{2} \mathrm{O}_{5} \mathrm{ha}^{-1}$ and $60 \mathrm{~kg}$ $\mathrm{K}_{2} \mathrm{O} \mathrm{ha}^{-1}$ at sowing, and then $45 \mathrm{~kg} \mathrm{P}_{2} \mathrm{O}_{5} \mathrm{ha}^{-1}, 2.2 \mathrm{~kg} \mathrm{~B} \mathrm{ha}^{-1}$ as boron calcite, and $500 \mathrm{~kg} \mathrm{ha}^{-1}$ of calcium sulphate in autumn 2001 and 2002. More information is in Ovalle et al. (2005).

\section{Evaluations and statistic analyses}

The evaluations carried out were: a) number of seedlings in winter using a cylinder of $10 \mathrm{~cm}$ in diameter and taking five samples per plot (between 2000 and 2002); b) DM production at the end of the growing season (November) using quadrants of $0.5 \mathrm{~m}^{2}$ (two samples per plot and $5 \mathrm{~cm}$ of cutting height) and then separating the sown species from others; c) pods (new plus the residual from previous years) and seed production $\left(\mathrm{g} \mathrm{m}^{-2}\right)$ at the end of each growing season using two quadrants of $20 \mathrm{x}$ $20 \mathrm{~cm}$ per plot; seeds were removed from pods by hand; d) percentage of hard-seeds in autumn (April), by testing germination of 50 seeds from each plot in Petri dishes at $20{ }^{\circ} \mathrm{C}$ in an incubator. Days to first flower were obtained from a previous experiment conducted in microplots in rise beds (Ovalle et al., 2003).

ANOVAs and multiple comparison test (least significant difference, LSD) were performed to pasture production and seed yield data using SPSS 12.0 statistical packages (SPSS, 2003).

Table 1. Cultivars of the different species of annual legumes tested in two experiments in the subhumid Mediterranean climate zone of central Chile.

\begin{tabular}{lll}
\hline \multirow{2}{*}{ Species } & \multicolumn{2}{c}{ Cultivars } \\
\cline { 2 - 3 } Medicago polymorpha & Experiment 1: 1997-1999 & Experiment 2: 2000-2002 \\
Biserrulla pelecinus & Cauquenes-INIA & Cauquenes-INIA \\
Ornithopus compressus & Mor96, Casbah & Mor96, Casbah \\
Trifolium subterraneum & Eneabba, Madeira, Paros, & Avila, Charano, Madeira, \\
\hline
\end{tabular}




\section{RESULTS}

\section{Climatic conditions during the experimental period}

A large variation in annual rainfall was registered during the studied period; in the first experiment (19971999) the annual rainfall ranged between 229 and 986 $\mathrm{mm}$, and in the second experiment (2000-2002) between 741 and $982 \mathrm{~mm}$ (Table 2). Both 1997 and 2002 were under the influence of "El Niño" stream and were "humid" years, whereas 1998 was a "dry" year, with respect to long-term rainfall data for the area.

\section{Plant density}

Plant density was measured in Experiment 2; in the first growing season (2000) plant density was lower than 400 plants $\mathrm{m}^{-2}$. The regeneration of the annual legume pasture in the second growing season was highly variable depending on hardseededness and the seed yield during the first growing season. For instance, plant density was very low in biserrula cultivars (19-44 plants $\mathrm{m}^{-2}$ ), had a wide range in serradella cultivars (26-2500 plants $\left.\mathrm{m}^{-2}\right)$ and was high in bur medic ( 1670 plants $\mathrm{m}^{-2}$ ) and sub clover (3100-4800 plants $\mathrm{m}^{-2}$ ) (Figure 1). In the third growing season a great increase was observed in both cultivars of biserrulla $\left(\approx 1000\right.$ plants $\left.\mathrm{m}^{-2}\right)$ and in some serradela cultivars (Santorini, Avila and Madeira); sub clover cv. Seaton Park had a great reduction in plant density but not cv. Clare, which reached 1800 plants $\mathrm{m}^{-2}$ (Figure 1). Bur medic showed a large plant population in winter (2000 plants $\mathrm{m}^{-2}$ ) but very few plants survived to maturity.

\section{Flowering time, pasture productivity and persistence}

Bur medic cv. Cauquenes-INIA was the most precocious (early-flowering), while yellow serradella cv. Avila was the last to flower (Table 3). A large range in flowering time was observed among cultivars of yellow serradella (106-143 d). Biserrula flowered later than the cultivars of subterranean clover.

Pasture productivity showed large variations among cultivars and years (Table 3 ). In both experiments, the year $\mathrm{x}$ cultivar interactions on DM production and seed yield were highly significant $(\mathrm{P}<0.001)$ (Table 4$)$. In the year of pasture seeding, DM production and seed yield of annual legumes were far superior in Experiment 1 than in Experiment 2 (Figures 2 and 3). This was a consequence of the heavy rains, particularly in October-November, occasioned by the "El Niño" effect in 1997 (Table 2). The $\mathrm{DM}$ production in the first year was significantly $(\mathrm{P}<$ 0.05) different among cultivars in Experiment 1, being

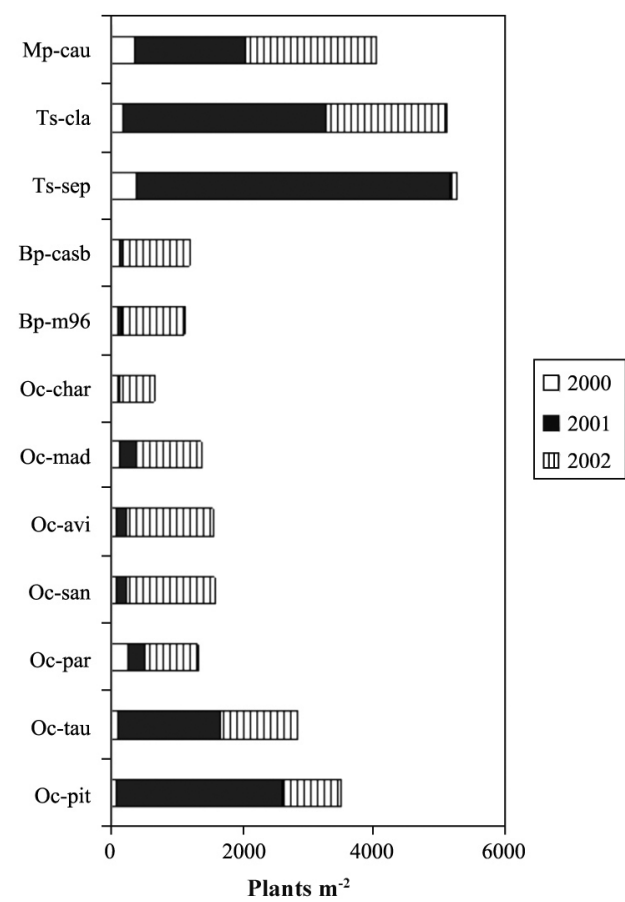

Medicago polymorpha $\mathrm{cv}$. Cauquenes (Mp-cau), Trifolium subterraneum cvs. Clare (Ts-cla) and Seaton Park (Ts-sep), Biserrula pelecinus cvs. Casbah (Bp-casb) and Mor96 (Bp-m96), and Ornithopus compressus cvs. Avila (Oc-avi), Charano (Oc-char), Madeira (Oc-mad), Paros (Oc-par), Pitman (Oc-pit), Santorini (Oc-san) and Tauro (Oc-tau)

Figure 1. Plant density measured in July-August of $\mathbf{1 6}$ annual legumes grown on hillside during the period 2000-2002 (Experiment 2).

Table 2. Monthly precipitation at Cauquenes-INIA Research Station (35'58' S, $72^{\circ} 17^{\prime}$ W; 140 m.a.s.l.).

\begin{tabular}{|c|c|c|c|c|c|c|c|c|c|c|c|c|c|}
\hline Year & $\mathbf{J}$ & $\mathbf{F}$ & $\mathbf{M}$ & $\mathbf{A}$ & M & $\mathbf{J}$ & $\mathbf{J}$ & $\mathbf{A}$ & $\mathbf{S}$ & $\mathbf{O}$ & $\mathbf{N}$ & D & Total \\
\hline 1997 & 1.3 & 7.0 & 0.6 & 127.7 & 145.6 & 302.1 & $\begin{array}{r}\mathrm{mm} \\
60.2\end{array}$ & 71.6 & 63.0 & 125.0 & 62.2 & 19.7 & 986.0 \\
\hline 1998 & 0.0 & 0.0 & 2.8 & 24.3 & 66.6 & 54.7 & 15.4 & 30.5 & 31.9 & 0.0 & 2.4 & 0.0 & 228.6 \\
\hline 1999 & 0.4 & 0.0 & 23.8 & 0.6 & 67.3 & 130.4 & 74.5 & 72.3 & 164.1 & 7.1 & 0.4 & 7.0 & 547.9 \\
\hline 2000 & 0.0 & 42.5 & 0.0 & 4.5 & 44.7 & 457.1 & 26.6 & 20.4 & 135.4 & 2.6 & 5.0 & 2.1 & 740.9 \\
\hline 2001 & 11.8 & 0.0 & 1.1 & 26.0 & 204.6 & 95.2 & 250.7 & 94.4 & 40.9 & 11.8 & 10.7 & 0.0 & 747.2 \\
\hline 2002 & 0.0 & 68.8 & 57.4 & 32.3 & 136.9 & 174.8 & 72.6 & 256.4 & 53.2 & 86.1 & 31.6 & 0.0 & 970.1 \\
\hline $\mathrm{X}_{1959-2002}$ & 6.5 & 6.3 & 11.7 & 38.8 & 120.4 & 157.2 & 130.1 & 83.7 & 55.4 & 27.4 & 16.2 & 8.7 & 657.0 \\
\hline
\end{tabular}


Table 3. Days to first flower (in the year of establishment) and mean ( \pm standard error) dry matter of annual legumes growing in the subhumid Mediterranean climate zone of central Chile. Values for each year are mean of the two experiments.

\begin{tabular}{|c|c|c|c|c|c|}
\hline \multirow[b]{2}{*}{ Species } & \multirow[b]{2}{*}{ Cultivar } & \multirow{2}{*}{$\begin{array}{c}\text { Days to } \\
\text { first } \\
\text { flower }^{1}\end{array}$} & \multicolumn{3}{|c|}{ Dry matter } \\
\hline & & & Year 1 & Year 2 & Year 3 \\
\hline & & & & $-\mathrm{g} \mathrm{m}^{-2}$ & \\
\hline Medicago polymorpha & Cauquenes (Mp-cau) & 97 & $285 \pm 167$ & $388 \pm 115$ & $91 \pm 91$ \\
\hline \multirow[t]{2}{*}{ Trifolium subterraneum } & Clare (Ts-cla) & 118 & $444 \pm 257$ & $253 \pm 106$ & $285 \pm 103$ \\
\hline & Seaton Park (Ts-sep) & 101 & $333 \pm 187$ & $241 \pm 13$ & $197 \pm 15$ \\
\hline \multirow[t]{2}{*}{ Biserrulla pelecinus } & Mor96 (Bp-m96) & 123 & $301 \pm 77$ & $81 \pm 46$ & $673 \pm 201$ \\
\hline & Casbah (Bp-casb) & 124 & $363 \pm 225$ & $19 \pm 1$ & $700 \pm 84$ \\
\hline \multirow[t]{8}{*}{ Ornithopus compressus } & Avila $(\text { Oc-avi })^{2}$ & 143 & 149 & 183 & 872 \\
\hline & Charano (Oc-cha $)^{2}$ & 108 & 193 & 49 & 480 \\
\hline & Eneabba $(\text { Oc-ene })^{2}$ & 111 & 122 & 255 & 469 \\
\hline & Madeira (Oc-mad) & 112 & $214 \pm 54$ & $257 \pm 29$ & $806 \pm 59$ \\
\hline & Paros (Oc-par) & 106 & $155 \pm 12$ & $110 \pm 5$ & $554 \pm 112$ \\
\hline & Pitman (Oc-pit) & 120 & $188 \pm 44$ & $327 \pm 20$ & $491 \pm 34$ \\
\hline & Santorini (Oc-san) & 110 & $228 \pm 53$ & $159 \pm 35$ & $486 \pm 182$ \\
\hline & Tauro (Oc-tau) & 123 & $329 \pm 141$ & $320 \pm 41$ & $356 \pm 94$ \\
\hline
\end{tabular}

${ }^{1}$ From Ovalle et al. (2003).

${ }^{2}$ Data are from one experiment.

Table 4. Analysis of variance ( $F$ values) for dry matter and seed yield of annual legumes species growing in the subhumid Mediterranean climate zone of central Chile, in the periods 1997-1999 (Experiment 1) and 2000-2002 (Experiment 2).

\begin{tabular}{|c|c|c|c|c|}
\hline \multirow[b]{2}{*}{ Source } & \multicolumn{2}{|c|}{ Experiment 1} & \multicolumn{2}{|c|}{ Experiment 2} \\
\hline & Dry matter & Seed yield & Dry matter & Seed yiel \\
\hline & & 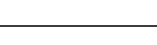 & & \\
\hline Block & $6.6 * * *$ & $3.9 *$ & 2.5 & 1.3 \\
\hline Year & $28.3 * * *$ & $146.9 * * *$ & $117.1 * * *$ & $67.5 * * *$ \\
\hline Cultivar & $3.2 * * *$ & $12.4 * * *$ & $4.4 * * *$ & $6.6 * * *$ \\
\hline Year * Cultivar & $9.7 * * *$ & $9.7 * * *$ & $7.0 * * *$ & $5.4 * * *$ \\
\hline
\end{tabular}

$* \mathrm{P}<0.05 ; * * \mathrm{P}<0.01 ; * * * \mathrm{P}<0.001$

higher in sub clover cv. Clare and biserrula cv. Casbah, but no differences $(\mathrm{P}>0.05)$ between cultivars were observed in Experiment 2. Seed yield in the first year was very high in biserrula in both experiments, and in bur medic in Experiment 1 (Figures $2 b$ and $3 b$ ).

In the second year, DM production and seed yield of cvs. Casbah and Mor96 biserrula and cvs. Charano, Paros and Santorini yellow serradela were much lower compared to bur medic or sub clover cv. Seaton Park (Figures 2 and 3; Table 3). However, a remarkable DM production was observed in biserrula and in some cultivars of yellow serradella (cv. Madeira) in the third growing season, in both experiments (Figures 2 and 3; Table 3). Biserrula produced also the largest number of seeds per $\mathrm{m}^{2}$ especially in the first year (data not shown). By contrast, a very low persistence was observed in burr medic after $3 \mathrm{yr}$.

The relationship between the cumulative DM and seed yield along the three growing seasons of each experiment, showed a clear separation between cultivars. The biserrula cultivars appear in the upper right extreme of the plots, indicating high DM production and high seed yield, and therefore good persistence (Figure 4). Among serradela, cvs. Madeira and Santorini also appear in the upper right part of the plot in the Experiment 2 (Figure 4b) and in the lower right side (cv. Madeira) and the left upper side (cv. Santorini) in Experiment 1 (Figure 4a). Bur medic had 

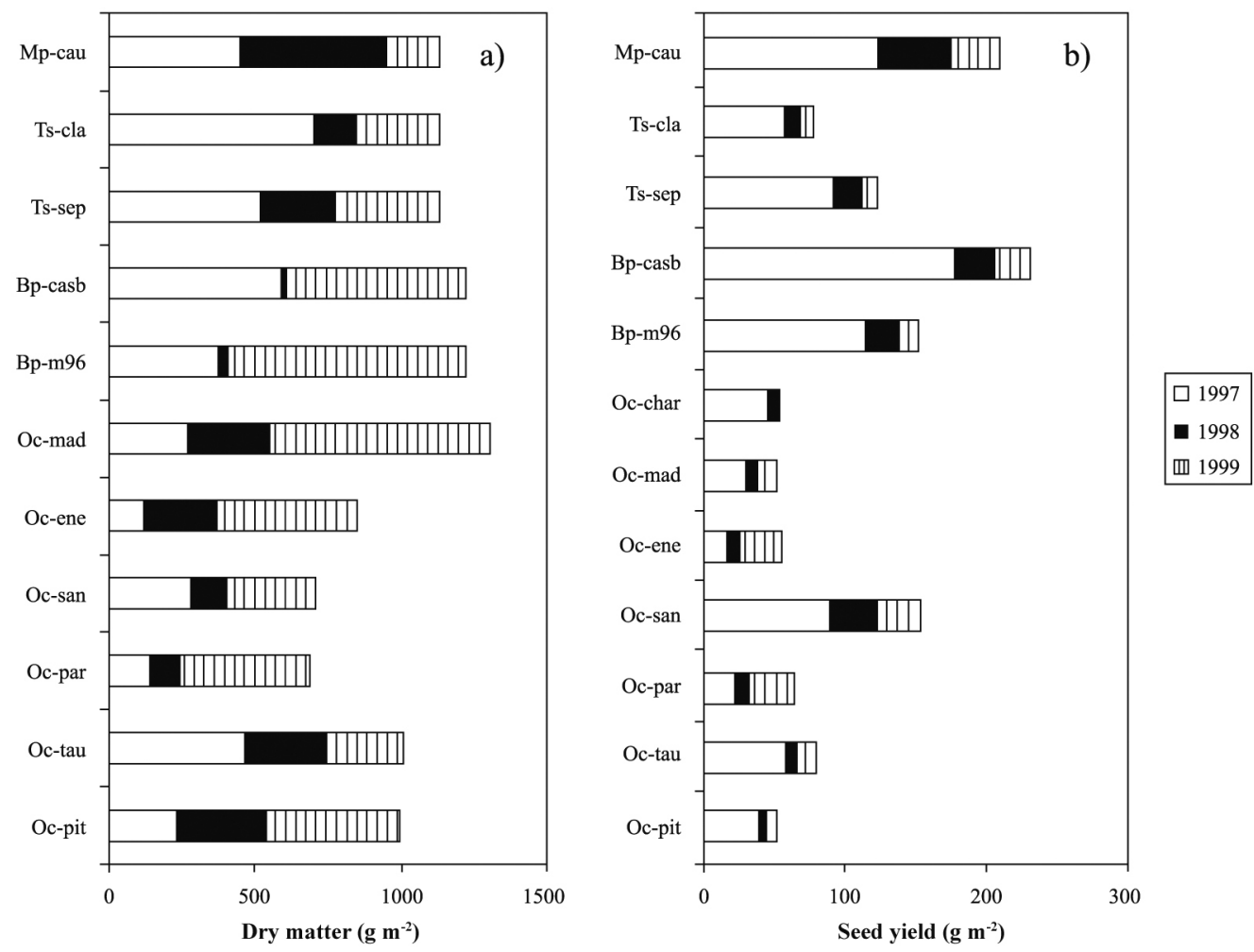

Medicago polymorpha cv. Cauquenes (Mp-cau), Trifolium subterraneum cvs. Clare (Ts-cla) and Seaton Park (Ts-sep), Biserrula pelecinus cvs. Casbah (Bp-casb) and Mor96 (Bp-m96), and Ornithopus compressus cvs. Charano (Oc-char), Madeira (Oc-mad), Paros (Oc-par), Pitman (Oc-pit), Santorini (Oc-san) and Tauro (Oc-tau).

Figure 2. Dry matter production (a) and seed yield (b) of annual legumes grown in the subhumid Mediterranean climate zone of central Chile, in the period 1997-1999 (Experiment 1).

high productivity in Experiment 1 (upper right extreme in Figure 4a) but had a poor performance in Experiment 2 (lower left extreme in Figure 4b). Sub clover had a good performance in the first and second year but fair in the third year (Table 3).

\section{Hard-seeds}

The percentage of hard-seeds was higher in biserrula and lower in sub clover (Table 4). Among serradela cvs. Paros and Santorini showed higher percentage of hardseeds, similar to biserrula, but others (cv. Eneabba) had much lower percentage. Bur medic had high percentage of hard-seeds in the first year but it declined in the following years due to the process of seed softening (Table 5).

\section{DISCUSSION}

Cultivars of biserrula and yellow serradella evaluated in this study appear very promising for pasture-crop rotation in hillsides. Both serradella and biserrula have a semi-erect growth habit and it seems that they can achieve larger plant size compared to sub clover, which has a more creeping growth habit. Biserrula is a prolific seed producer with small seed and a high level of hardseededness (Loi et al., 1997; 1999); cvs. Mor96 and Casbah were able to develop a large seed bank over the three growing seasons of the two experiments. This was achieved when seeded in a favorable year like 1997 in Experiment 1 or in a normal year like 2000 in Experiment 2. Despite being later flowering compared with the reference bur medic, both cultivars showed greater than average seed production in a 'dry' year (1998); this result is consistent with the relatively deep rooting patterns observed for this species (Loi et al., 2005). The natural re-establishment in the second year was low; however, in the third year self seeding was optimal, assuring the longer term persistence of biserrula. This performance has been described in biserrula by several authors and it is explained by the high amount of hard-seeds produced by this species (Howieson et al., 1995; Loi et al., 1999; Ovalle et al., 2004).

Hardseededness, or impermeability of the seed coat to water, is the most important long-term dormancy mechanism in Mediterranean legumes. Both genetic and environmental factors control hardseededness. In 

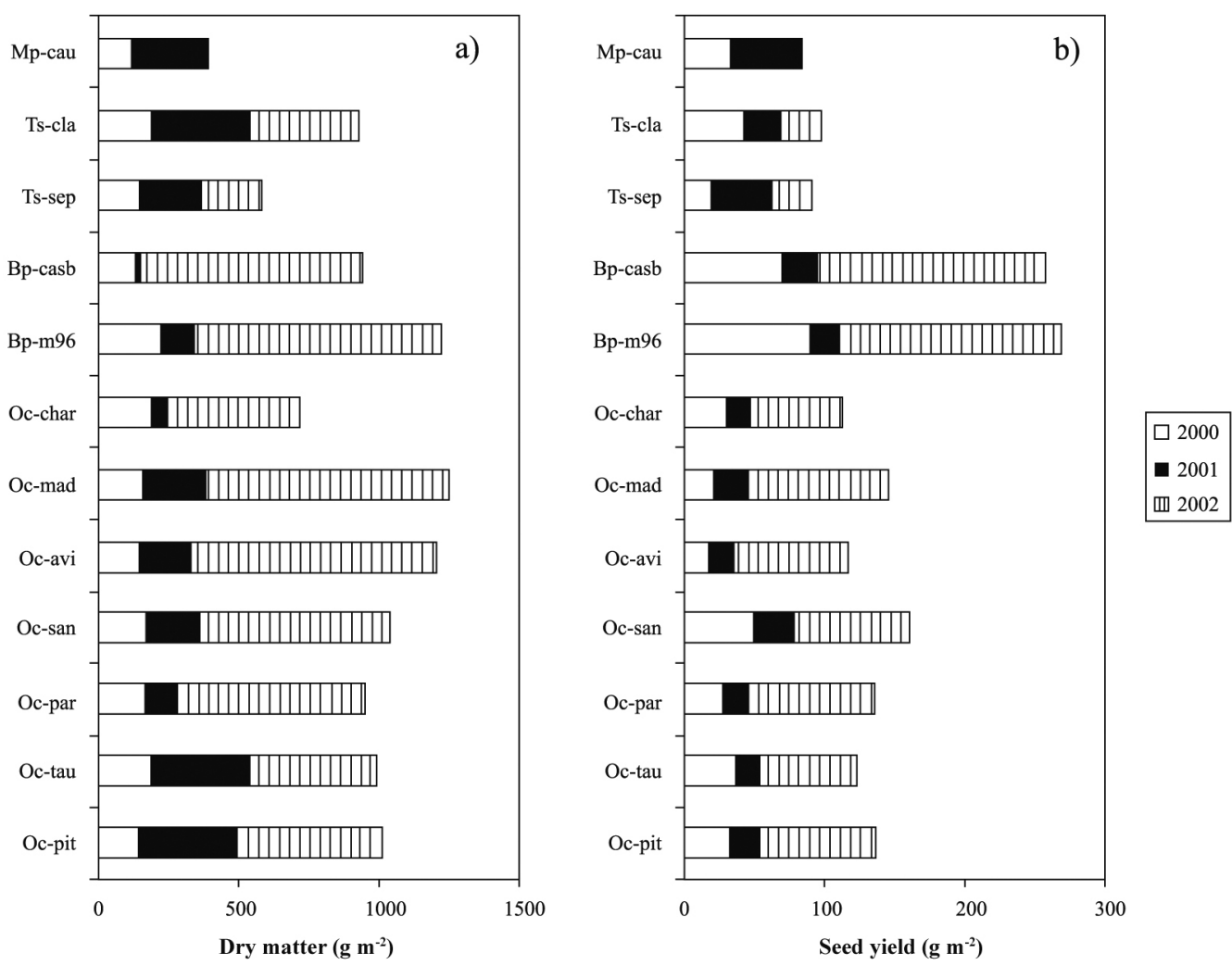

Medicago polymorpha cv. Cauquenes (Mp-cau), Trifolium subterraneum cvs. Clare (Ts-cla) and Seaton Park (Ts-sep), Biserrula pelecinus cvs. Casbah (Bp-casb) and Mor96 (Bp-m96), and Ornithopus compressus cvs. Avila (Oc-avi), Charano (Oc-char), Madeira (Oc-mad), Paros (Oc-par), Pitman (Ocpit), Santorini (Oc-san) and Tauro (Oc-tau).

Figure 3. Dry matter production (a) and seed yield (b) of annual legumes grown in the subhumid Mediterranean climate zone of central Chile, in the period 2000-2002 (Experiment 2).

field conditions, seed impermeability is broken by the influence of diurnal fluctuating temperatures and other natural or artificial processes that scarify the seed coat to produce 'soft' seed (Lodge et al., 1990). Hard-seeds are necessary to develop a seed bank from which the legumes will spontaneously re-establish each season (Cocks, 1988; Taylor et al., 1991; Loi et al., 1999). In general, newly ripened seeds of annual legumes have high levels of hardseeds, but the rate of seed softening under field conditions differs greatly among accessions and between species. For example, seed softening occurs very rapidly in Trifolium subterraneum and T. isthmocarpum, but the opposite is true in Ornithopus compressus and Biserrula pelecinus (Table 5; Revell et al., 1998; Norman et al., 1998; Loi et al., 1999). Furthermore, in annual medics (Medicago spp.) and $T$. subterraneum, the rate of seed softening decreases as depth of burial increases (Taylor and Ewing, 1996), whereas in $O$. compresus and $B$. pelecinus softening occurs more rapidly at $2 \mathrm{~cm}$ depth than at $6 \mathrm{~cm}$ (Revell et al., 1998; Loi et al., 1999). An experiment conducted in Chile (at the same experimental site of the present work) showed that pods of bur medic placed in soil surface had $97 \%$ of hard-seeds after the first summer and reached $17 \%$ after 5 years (Avendaño et al., 1997).

Among yellow serradella cvs. Madeira and Santorini have similar precocity (110-112 d to first flower) and both are highly productive; 'Madeira' produced more DM but 'Santorini' more seeds. In a "humid" year (2002), serradella and biserrula produced about two times more DM than sub clover cv. Clare $\left(\sim 800\right.$ vs. $\left.400 \mathrm{~g} \mathrm{~m}^{-2}\right)$ and with lower number of plants per $\mathrm{m}^{2}$ (1000-1500 plants $\mathrm{m}^{-2}$ in the formers and 2500 plants $\mathrm{m}^{-2}$ in sub clover).

Seed size of yellow serradella is about two times greater than of biserrula (Ovalle et al., 2003), and seed recovery is low $(\sim 10 \%)$ after being ingested by sheep (Edward et al., 1998). These seed characteristics suggest a more careful management of serradella pastures during summer, in terms of grazing pressure may be required. In biserrula the small seed size of provide a further advantage when the pasture is grazed because seed viability is less affected after being ingested by sheep (Squella, 1992; Edward et al., 1998). 

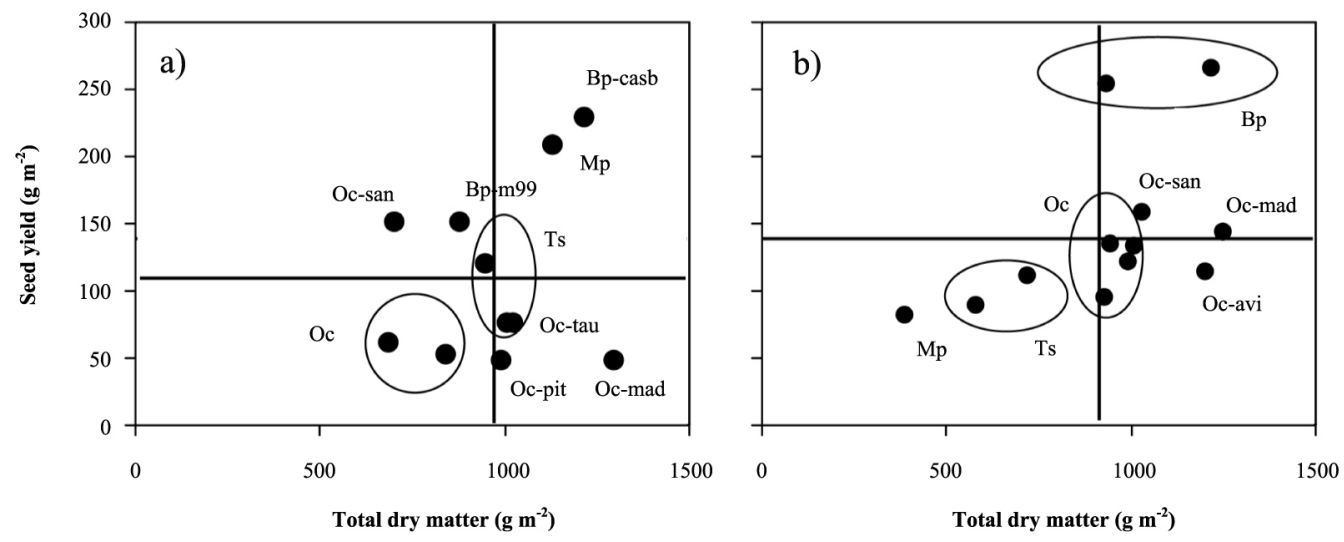

Medicago polymorpha cv. Cauquenes (Mp-cau), Trifolium subterraneum cvs. Clare (Ts-cla) and Seaton Park (Ts-sep), Biserrula pelecinus cvs. Casbah (Bp-casb) and Mor96 (Bp-m96), and Ornithopus compressus cvs. Avila (Oc-avi), Charano (Oc-char), Madeira (Oc-mad), Paros (Oc-par), Pitman (Ocpit), Santorini (Oc-san) and Tauro (Oc-tau).

Figure 4. Relationships between dry matter production and seed yield of annual legumes over three growing seasons, 1997-1999 (a) and 2000-2002 (b). Lines represent the average values for all cultivars.

According to Nichols et al. (2006) the preferred texture of serradella and biserulla range from sand to loam soils, however in these experiments both species performed well in a more heavy soil texture (sandy clay loam) and imperfect drainage. Sandy loam textures are common in volcanic soils (Andisol) in Chile where yellow serradela has been naturalized (Ovalle et al., 2006c). Also, both yellow serradela and biserrula can tolerate a wide range of soil $\mathrm{pH}$, including acid soils (Nichols et al., 2006), which is another important trait to ensure adaptation and persistence of annual legume pastures in the Mediterranean region of Chile, where soil $\mathrm{pH}$ is 5-6.

Soil characteristics and rizhobia strains are important factors for $\mathrm{N}$ fixation and annual legume persistence. The four species studies in this work differ in nodulating species (Temprano et al., 2008); biserrula is nodulated by Mesorhizobium ciceri bv. biserrula (Nandasena et al., 2006; 2007; Temprano et al., 2008), serradella bv.

Table 5. Percentage of hard-seeds of annual legumes growing in the subhumid Mediterranean climate zone of central Chile. Values were measured in April of each year in Experiment 1.

\begin{tabular}{|c|c|c|c|c|}
\hline \multirow[b]{2}{*}{ Species } & \multirow[b]{2}{*}{ Cultivar } & \multicolumn{3}{|c|}{ Hard-seeds ${ }^{1}$} \\
\hline & & Year 1 & Year 2 & Year 3 \\
\hline & & & $\%$ & \\
\hline Medicago polymorpha & Cauquenes & 95.4 & 66.7 & 68.2 \\
\hline \multirow{2}{*}{ Trifolium subterraneum } & Clare & 67.4 & 8.2 & 39.0 \\
\hline & Seaton Park & 39.1 & 10.8 & 28.5 \\
\hline \multirow[t]{2}{*}{ Biserrulla pelecinus } & Mor96 & 100 & 98.2 & 99.9 \\
\hline & Casbah & 99.9 & 99.2 & 99.8 \\
\hline \multirow[t]{6}{*}{ Ornithopus compressus } & Eneabba & 25.1 & 61.9 & 92.8 \\
\hline & Madeira & 98.9 & 76.4 & 96.3 \\
\hline & Paros & 99.6 & 97.5 & 97.6 \\
\hline & Pitman & 93.2 & 33.3 & 97.5 \\
\hline & Santorini & 99.4 & 97.8 & 96.7 \\
\hline & Tauro & 33.6 & 93.9 & 94.4 \\
\hline
\end{tabular}

${ }^{1}$ In year 1 correspond to freshly produced seeds and in years 2 and 3 to whole seed reserve (seed stock). 
Bradyrhizobium sp. strains (Stępkowski et al., 2005; Temprano et al., 2008), bur medic by Sinorhizobium meliloti and Sinorhizobium medicae (Charman and Ballard, 2004; Denton et al., 2007; Temprano et al., 2008), and sub clover by Rhizobium leguminosarum bv. trifolii (Temprano et al., 2008). Observations of nodulating plants in old experimental plots in the same Experimental Center Cauquenes, indicate that the survival and persistence of Mesorhizobium and Bradyrhizobium in granitic soils is remarkable after 6-8 years of pasture establishment. Also, determination of $\mathrm{N}$ fixation using the ${ }^{15} \mathrm{~N}$ natural abundance technique showed greater $\mathrm{N}$ content in DM and $\mathrm{N}$ fixation in yellow serradela $\mathrm{cv}$. Tauro (91 kg N ha-1) compared with bur medic and sub clover (Ovalle et al., 2006b). Other study conducted in Australia showed also higher rate of $\mathrm{N}$ fixation in yellow serradella than burr medic and sub clover (Sanford et al., 1994).

Our results indicate that biserrula and yellow serradela can be used in monoculture or in mixture with other annual legumes, in both pasture-crop rotation and permanent pastures. The use of these species would contribute to the economic and ecological improvement of the prevailing productive systems in the Mediterranean climate region of central Chile (Ovalle et al., 1999).

\section{CONCLUSIONS}

The productivity and persistence of serradela and biserrula cultivars are clearly superior to bur medic or sub clover, which are the most common annual legumes seeded in the area. Compared to the reference species, subterranean clover and bur medic, they have higher pasture production, seed yield, hardseededness and persistence. Furthermore, these new species have the advantage that seed harvesting is much easier (and in some species cheaper) compared to bur medic or sub clover, which could facilitate a local production of seeds.

\section{ACKNOWLEDGEMENTS}

This research was funded by FONDECYT 1000608. We thank Centre for Legumes in Mediterranean Agriculture (CLIMA), Australia, and Drs. Mike Ewing, John Howieson and Steve Carr, for providing most of the cultivars and rhizobium. To Dr. Angelo Loi for comments to an early version of the manuscript. To Teresa Aravena for field assistance and José Cares for helping in data analysis.

\section{RESUMEN}

Productividad y persistencia de serradela amarilla (Ornithopus compressus L.) y biserrula (Biserrula pelecinus L.) en la región climática mediterránea de Chile central. La producción y la sostenibilidad de las praderas de secano en la región de clima mediterráneo de Chile central están actualmente limitadas por la baja diversidad de especies valiosas y cultivares de leguminosas forrajeras anuales, capaces de persistir en zonas con precipitaciones anuales sumamente variables, y suelos de baja fertilidad o de mal drenaje. En este trabajo se evaluó la producción de fitomasa, producción de semilla, dureza seminal y la persistencia de cultivares de serradela amarilla (Ornithopus compressus L.) y biserrula (Biserrula pelecinus L.), en experimentos de campo conducidos en la región mediterránea subhúmeda de Chile. La hualputra (Medicago polymorpha L.) y el trébol subterráneo (Trifolium subterraneum L.) fueron utilizados como especies de referencia. La producción de fitomasa y de semillas fue considerablemente más alta en biserrula (cvs. Mor96 y Casbah), y en algunos cultivares de serradella amarilla (e.g. Madeira y Santorini); biserrula produjo el mayor número de semillas por $\mathrm{m}^{2}$. Como era esperable en especies que presentan niveles muy altos de semillas duras, la recuperación de la pradera en el segundo año fue débil, pero la densidad de plantas y productividad fue alta en la tercera temporada de crecimiento. El uso de biserrula y serradela en monocultivo o en mezcla con otras leguminosas anuales, tanto en rotación con cultivos como en praderas permanentes, podrá contribuir al mejoramiento de los sistemas productivos en la región mediterránea de Chile central.

Palabras clave: dureza seminal, densidad de plantas, espinal, leguminosa anual, producción de semillas.

\section{LITERATURE CITED}

Avendaño, J., A. del Pozo, and C. Ovalle. 1999. Hardseededness under field conditions of Medicago polymorpha during five softening seasons in the Mediterranean zone of Chile. In Buchanan, J.G., L.D. Bailey, and P McCaughey (eds.) Proceeding of the XVIII International Grassland Congress, Winnipeg and Saskatoon, Canada. 1997. CD version, Session 19:89-90.

Charman, N., and R.A. Ballard. 2004. Burr medic (Medicago polymorpha L.) selections for improved $\mathrm{N}_{2}$ fixation with naturalised soil rhizobia. Soil Biol. Biochem. 36:1331-1337. 
Cocks, P.S. 1988. Seed production and seed survival under grazing of annual medics (Medicago spp.) in north Syria. J. Agric. Sci. (Cambridge) 110:455-463.

Dear, B.S, B.C.D. Wilson, C.A. Rodham, P. McCaskie, and G.A. Sandral. 2002. Productivity and persistence of Trifolium hirtum, T. michelianum, T. glanduliferum and Ornithopus sativus sown as monocultures or in mixtures with $T$. subterraneum in the south-eastern Australian wheat belt. Aust. J. Agric. Res. 42:549-556.

del Pozo, A., C. Ovalle, J. Aronson, and J. Avendaño. 2002a. Ecotypic differentiation in Medicago polymorpha along an environmental gradient in central Chile. I. Phenology, winter vigor and biomass production. Plant Ecol. 159:119-130.

del Pozo, A., C. Ovalle, J. Aronson, and J. Avendaño. 2002b. Ecotypic differentiation in Medicago polymorpha along an environmental gradient in central Chile. II. Winter growth as related to phenology and temperature. Plant Ecol. 160:53-59.

del Pozo, A., C. Ovalle, J. Avendaño, T. Aravena, y M.E. Díaz. 2001. Combarbalá-INIA, un cultivar precoz de hualputra (Medicago polymorpha), para áreas de secano mediterráneo. Agric. Téc. (Chile) 61:93-96.

Denton, M.D., C.R. Hill, W.D. Bellotti, and D.R. Coventry. 2007. Nodulation of Medicago truncatula and Medicago polymorpha in two pastures of contrasting soil $\mathrm{pH}$ and rhizobial populations. Appl. Soil Ecol. 35:441-448.

Edward, A.Y., M.A. Ewing, and C.K. Revell. 1998. Fate of serradella, medic and biserrula seeds in pods ingested by sheep. Proceedings of the $9^{\text {th }}$ Australian Agronomy Conference, Wagga Wagga. July 1998. Available at http://www.regional.org.au/ au/asa/1998/1/289edward.htm (accessed November 2008).

Freebairn, R.D. 1994. Serradela: an advisory perspective. In Michalk, D., A. Craig, and B. Collins (eds.) Technical Report No 219. p. 61-65. Primary Industries South Australia, Adelaide, South Australia, Australia.

Howieson, J.G., A. Loi, and S.J. Carr. 1995. Biserrula pelecinus $\mathrm{L}$. a legume pasture species with potential for acid, duplex soils which is nodulated by unique root-nodule bacteria. Aust. J. Exp. Agric. 46:9971009.

Lodge, G.M., R.D. Murison, and E.W. Heap. 1990. The effect of temperature on the hardseed content of some annual legumes grown on the northern slopes of New South Wales. Aust. J. Exp. Agric. 41:941-955.

Loi, A., P.S. Cocks, J.G. Howieson, and S.J. Carr. 1997. Morphological characterization of Mediterranean populations of Biserrula pelecinus. Plant Breed. 116:171-176.
Loi, A., J.G. Howieson, P.S. Cocks, and S.J. Carr. 1999. Hardseededness and the pattern of softening in Biserrula pelecinus L. and Ornithopus compressus L. and Trifolium subterraneum L. seeds. Aust. J. Agric. Res. 50:1073-1081.

Loi, A., J.G. Howieson, B.J. Nutt, and S.J. Carr. 2005. A second generation of annual pasture legumes and their potential for inclusion in Mediterranean-type farming system. Aust. J. Exp. Agric. 45:289-299.

Nandasena, K.G., G.W. O'Hara, R.P. Tiwari, A. Willlems, and J.G. Howieson. 2007. Mesorhizobium ciceri biovar biserrulae, a novel biovar nodulating the pasture legume Biserrula pelecinus L. Int. J. Syst. Evol. Microbiol.57:1041-1045.

Nandasena, K.G., G.W. O'Hara, R.P. Tiwari, and J.G. Howieson. 2006. Rapid in situ evolution of nodulating strains for Biserrula pelecinus L. through lateral transfer of a symbiosis island from the original mesorhizobial inoculant. Appl. Environ. Microbiol. 72:7365-7367.

Nichols, P., A. Loi, M. Ewing, C. Revell, J. Howieson, et al. 2006. New annual pasture legumes for southern Australia - 15 years of revolution. In Proceedings of $13^{\text {th }}$ Agronomy Conference, Perth, Western Australia. 10-14 September 2006. Australian Society of Agronomy, Australia.

Norman, H.C., P.S. Cocks, F.P. Smith, and B.J. Nutt. 1998. Reproductive strategies in Mediterranean annual clovers: germination and hardseededness. Aust. J. Agric. Res. 49:973-982.

Ovalle, C., J. Aronson, A. del Pozo, and J. Avendaño. 1999. Restoration and rehabilitation of mixed espinales in central Chile: 10-year report and appraisal. Arid Soil Res. 13:369-381.

Ovalle, C., S. Arredondo, A. del Pozo, J. Avendaño, y F. Fernández. 2004. Atributos y antecedentes del comportamiento de Biserrula pelecinus L. Nueva leguminosa forrajera anual para Chile mediterráneo. Agric. Téc. (Chile) 64:74-81.

Ovalle, C., S. Arredondo, y O. Romero. 2006c. Serradela amarilla (Ornithopus compressus) y serradela rosada (O. sativus): dos nuevas especies de leguminosas forrajeras anuales para la zona mediterránea de Chile. Agric. Téc. (Chile) 66:196-209.

Ovalle, C., J. Avendaño, J. Aronson, and A. del Pozo. 1996. Land occupation patterns and vegetation structure in the anthropogenic savannas (Espinales) of central Chile. Forest Ecol. Manage. 86:129-139. 
Ovalle, C., J. Avendaño, A. del Pozo, C. Porqueddu, and S. Arredondo. 2000. Ten new annual legumes tested for unirrigated lands of the Mediterranean-climate region of Chile. $10^{\text {th }}$ Meeting of the FAO/CIHEAM Sub-network on Mediterranean Pastures and Fodder Crops, Sassari, Italy. April 2000. Cahiers Options Mediterranéennes 45:161-166.

Ovalle, C., A. del Pozo, J. Avendaño, T. Aravena, y M.E. Díaz. 2001. Cauquenes-INIA, nuevo cultivar de hualputra chilena (Medicago polymorpha), para áreas de secano mediterráneo. Agric. Téc. (Chile) 61:89-92.

Ovalle, C., A. del Pozo, J. Avendaño, P. Bustos, y S. Arredondo. 2003. Caracterización preliminar de una colección de leguminosas forrajeras anuales para la zona mediterránea de Chile. Agric. Téc. (Chile) 63:156-168.

Ovalle, C., A. del Pozo, J. Avendaño, F. Fernández, y S. Arredondo. 2005. Adaptación, crecimiento y producción de nuevas leguminosas forrajeras en la zona Mediterránea de Chile: II. Comportamiento de las especies en el secano interior subhúmedo, en suelos graníticos. Agric. Téc. (Chile) 65:265-277.

Ovalle, C., A. del Pozo, J.M. de Miguel, M.A. Casado, and B. Acosta. 2006a. Consequence of landscape heterogeneity on grassland diversity and productivity in the Espinal agroecosystem of central Chile. Landscape Ecol. 21:585-594.

Ovalle, C., S. Urquiaga, A. del Pozo, E. Zagal, and S. Arredondo. 2006b. Nitrogen fixation in six forage legumes in Mediterranean central Chile. Acta Agr. Scand. B-S P 56:277-283.

Paredes, M., V. Becerra, C. Rojo, A. del Pozo, C. Ovalle, and J. Aronson. 2002. Ecotypic differentiation in Medicago polymorpha L. along an environmental gradient in central Chile: RAPDs studies show little genetic variation. Euphytica 123:431-439.

Paynter, B.H. 1990. Comparative phosphate requirements of yellow serradela (Ornithopus compressus), burr medic (Medicago polymorpha) and subterranean clover (Trifolium subterraneum). Aust. J. Exp. Agric. 30:507-514.
Revell, C.K., G.B. Taylor, and P.S. Cocks. 1998. Longterm softening of surface and buried hard seeds of yellow serradella grown in a range of environments. Aust. J. Agric. Res. 49:673-685.

Sanford, P., J.S. Pate, and M.J. Unkovich. 1994. A survey of proportional dependence of subterranean clover and other pasture legumes on $\mathrm{N}_{2}$ fixation in SouthWest Australia utilizing ${ }^{15} \mathrm{~N}$ natural abundance. Aust. J. Agric. Res. 45:165-181.

SPSS. 2003. SPSS 12.0 for windows. SPSS Inc., Chicago, Illinois, USA.

Squella, F. 1992. The ecological significance of seed size in Mediterranean annual pasture legumes. $466 \mathrm{p}$. Ph.D. Thesis. The University of Australia, Adelaide, South Australia, Australia.

Stępkowski, T., L. Moulin, A. Krzyżańska, et al. 2005. European origin of Bradyrhizobium populations infecting lupins and serradella in soils of Western Australia and South Africa. Appl. Environ. Microbiol. 71:7041-7052.

Taylor, G.B., and M.A. Ewing. 1996. Effects of extended (4-12 years) burial on seed softening in subterranean clover and annual medics. Aust. J. Exp. Agric. 36:145150.

Taylor, G.B., R.A. Maller, and R.C. Rossiter. 1991. A model describing the influence of hardseededness on the persistence of an annual forage legume, in a ley farming system, in a Mediterranean-type environment. Agric. Ecosyst. Environ. 37:275-301.

Temprano, F.J., M. Albareda, and D.N. RodriguezNavarro. 2008. Rhizobium populations in grassland acid soils of Southwest Spain which nodulate Trifolium, Medicago, Ornithopus and Biserrula. In $12^{\text {th }}$ Meeting of the FAO/CIHEAM Sub-network on Mediterranean Pastures and Fodder Crops, Elvas, Portugal. April 2008. Cahiers Options Mediterranéennes 79:127-130. 